\title{
Identifikasi Patahan Pada Batuan Sedimen Menggunakan Metode Geolistrik Konfigurasi Dipole-Dipole di Tapak RDE Serpong, Banten
}

Hadi Suntoko*, Abimanyu Bondan Wicaksono

Pusat Kajian Sistem Energi Nuklir, Badan Tenaga Nuklir Nasional, Jl. Kuningan Barat, Mampang Prapatan, Jakarta Selatan, Indonesia 12710

\begin{tabular}{l}
\hline INFORMASI ARTIKEL \\
\hline RiwayatArtikel: \\
Diterima: \\
10 Januari 2018 \\
Diterima dalam bentuk revisi: \\
04 Maret 2018 \\
Disetujui: \\
03 April 2018 \\
\hline
\end{tabular}

Kata kunci:

Kelurusan

patahan

geolistrik

resistivitas

\begin{abstract}
ABSTRAK
IDENTIFIKASI PATAHAN PADA BATUAN SEDIMEN MENGGUNAKAN METODE GEOLISTRIK KONFIGURASI DIPOLE-DIPOLE DI TAPAK RDE SERPONG, BANTEN. Telah dilakukan identifikasi patahan menggunakan metode geolistrik dengan konfigurasi dipole- dipole yang melintang terhadap kelurusan berarah Tenggara-Baratlaut di tapak Reaktor Daya Ekperimental (RDE). Pengukuran geolistrik ini merupakan bagian kegiatan evaluasi tapak RDE Serpong untuk menunjukkan kelayakan tapak RDE dari patahan. Perka BAPETEN Nomor 8 tahun 2013 mensyaratkan bahwa tidak boleh terdapat patahan kapabel dalam radius $5 \mathrm{~km}$ dari tapak. Tujuan penelitian adalah membuktikan ada atau tidaknya patahan dalam radius $5 \mathrm{~km}$ berdasarkan analisis geolistrik. Metode yang digunakan adalah pendataan resisitivitas batuan bawah permukaan dalam konfigurasi dipole-dipole yang memiliki dua elektroda arus dan dua elektroda potensial. Interpretasi data geolistrik didasarkanpada pola resistivitas yang berkaitan dengan sifat fisik batuan/pelapisan. Batuan yang tidak terkonsolidasi dengan baik memberikan nilai resistivitas yang tinggi atau sebaliknya lapisan batuan yang kompak dan masiv yang ditunjukkan nilai resistivitas rendah. Hasil penelitian menunjukkan bahwa dalam radius $5 \mathrm{~km}$ pada formasi batuan batupasir dan batulempung tidak terdapat perbedaan pola resistivitas yang signifikan terkait dengan keberadaan patahan.
\end{abstract}

\begin{abstract}
IDENTIFICATION OF FAULT IN SEDIMENT LAYERS BY USING GEOELECTRICAL METHOD WITH DIPOLE-DIPOLE CONFIGURATION AT RDE SITE SERPONG, BANTEN. Fault identification has been done by using geoelectrical method with dipole-dipole configuration transverse to NorthWest-EastWest trending lineament at the Experimental Power Reactor (RDE) site. This geoelectric measurement is a part of RDE site evaluation to demonstrate the feasibility of the site from the fault existence, BAPETEN Regulation No. 8 year 2013 stipulates that site should be free from capable fault within a radius of $5 \mathrm{~km}$. The purpose of the study was to prove the inexistence of fault within a $5 \mathrm{~km}$ radius based on the geolectrical analysis. The method used resistivity data collection of subsurface rocks in a dipole-dipole configuration having one current electrode and two potential electrodes. The geoelectric data interpretation was based on the resistivity pattern which correlated to the physical properties of the rock formation. Unconsolidated rock layers provided a high resistivity value, while a compact and massive rock layer exhibited high resistivity values. The results showed that within a $5 \mathrm{~km}$ radius of sandstone and claystone formation the inexistence of any significant difference in the resistivity pattern associated with a fault.

Keywords: Lineament fault, geoelectrical, resistivity.
\end{abstract}

(c) 2017Jurnal Pengembangan Energi Nuklir. All rights reserved

\section{PENDAHULUAN}

Salah satu aspek untuk menentukan lokasi/tapak Pembangkit Listrik Tenaga Nuklir (PLTN) yang layak dan aman dari bahaya ekternal adalah aspek kegempaan. Aspek ini mempelajari bagaimana kondisi kestabilan wilayah yang diakibatkan oleh aktivitas tektonik/patahan, baik patahan disebabkan oleh gempa tektonik, maupun akibat dorongan tenaga endogen dari dalam bumi. Patahan merupakan salah satu bentuk struktur geologi yang terjadi oleh proses perubahan posisi batuan akibat bekerjanya tenaga endogen yang menekan struktur batuan keras sehingga antara struktur batuan/lapisan satu dan lainnya menjadi terpisah[1]. Terpisahnya pelapisan batuan skala besar maupun kecil dapat menimbulkan gerakan tanah/gempa yang dapat merusak bangunan yang ada di permukaan tanah.

Sesuai Peraturan Kepala BAPETEN Nomor 8 tahun 2013 tentang Evaluasi Tapak Instalasi Nuklir untuk Aspek Kegempaan, mensyaratkan bahwa dalam radius $5 \mathrm{~km}$ dari tapak PLTN tidak diizinkan adanya patahan kapabel[2]. Patahan kapabel adalah patahan yang mempunyai potensi signifikan untuk 


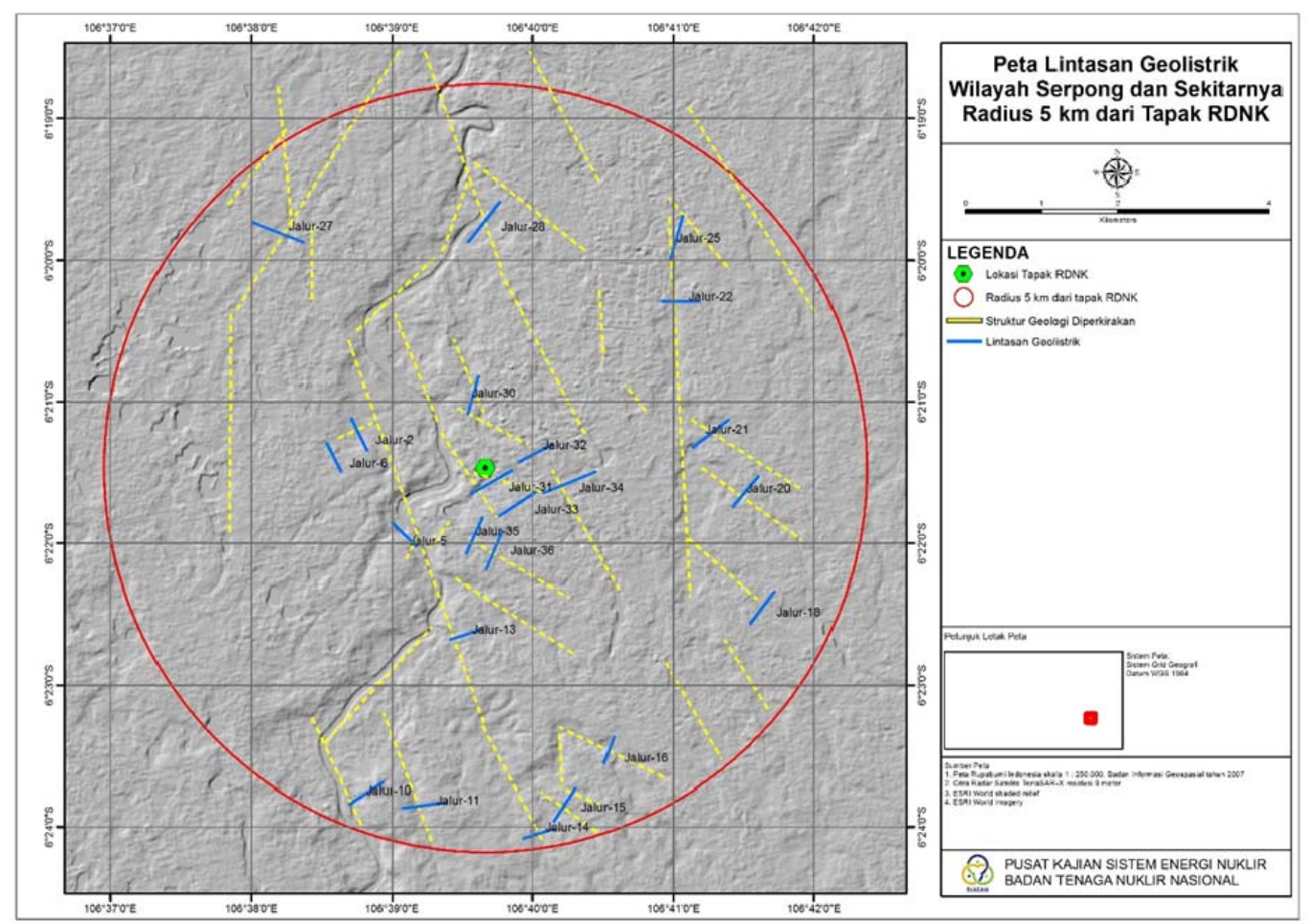

Gambar 1. Peta Lintasan Pengukuran Geolistrik di Sekitar Tapak RDE[6].

terjadinya pergeseran dekat permukaan tanah. Selain itu, jika patahan ini bergerak akan memicu patahan lain untuk bergerak. Aspek kegempaan umumnya terdiri dari pendataan geologi, geofisika dan geoteknik. Aspek kegempaan berperan penting untuk menyimpulkan kestabilan wilayah dalam rangka menentukan layak atau tidaknya tapak [3,4].

Berdasarkan peta geologi yang dipublikasikan oleh Pusat Penelitian dan Pengembangan Geologi, Bandung, menunjukkan bahwa tapak RDE Serpong yang termasuk dalam wilayah Peta Geologi lembar Jakarta tersusun atas sebaran Alluvial, Tufa pasiran Endapan Gunungapi Muda, Formasi Serpong, Formasi Genteng dan Formasi Bonjongmanik dengan perubahan variasi litologi baik secara vertikal maupun lateral [5]. Peta struktur geologi regional wilayah Jawa dan sekitarnya menunjukkan pola patahan berarah Tenggara - Baratlaut[6]. Untuk menjamin keselamatan tapak RDE, perlu dilakukan identifikasi kelurusan terindikasi patahan menggunakan lintasan geolistrik seperti diperlihatkan pada Gambar 1 dan Tabel 1.
Tujuan penelitian adalah membuktikan keberadaan patahan/struktur geologi bawah permukaan menggunakan pendataan geolistrik untuk menganalisis resistivitas batuan dalam radius permukaan $5 \mathrm{~km}$ dari tapak RDE. Penelitian ini dilakukan sebagai bagian dari pemenuhan salah satu syarat izin tapak yakni pada aspek kegempaan[6].

Identifikasi struktur geologi terkait pendataan elemen struktur geologi merupakan kegiatan menggunakan intepretasi data permukaan melalui survei lapangan. Sedangkan analisis geofisika digunakan untuk memperoleh data pelapisan batuan hingga kedalaman 200 meter[7]. Survei identifikasi struktur geologi diawali dengan diawali dengan analisis citra Digital Elevation Model (DEM) beresolusi tinggi[8]. DEM memberikan informasi kelurusan-kelurusan yang diduga patahan berdasarkan pola kontur sungai, lembah, danau dan gawir. Kelurusan tersebut dibuktikan melalui konfirmasi lapangan dan deskripsi batuan di lokasi pengamatan yang diduga sebagai jalur patahan[1]. Kelurusan terindikasi patahan kemudian dibuktikan menggunakan metode geofisika misalnya metode geolistrik[9]. Hasil penelitian ini diharapkan dapat memberikan informasi awal 
mengenai aman tidaknya tapak RDE dari patahan kapabel.

\section{PRINSIP DASAR GEOLISTRIK DENGAN KONFIGURASI DIPOLE- DIPOLE}

Prinsip dasar metode geolistrik yakni dengan memberikan informasi nilai resistivitas (tahanan jenis) batuan bawah permukaan dengan cara mengalirkan arus Direct Current (DC)atau arus searah yang ditangkap oleh elektroda untuk menggambarkan kondisi lapisan batuan bawah permukaan. Besaran beda potensial menghasilkan perbedaan resistivitas yang kemudian diolah menjadi informasi batuan dan dapat digunakan untuk mengintepretasikan keberadaan suatu patahan/struktur geologi[10].

Kegiatan pengukuran resistivitas batuan dari geolistrik menggunakan informasi rambatan arus listrik ke dalam bumi. Prinsipnya bahwa setiap arus listrik dapat dirambatkan tergantung pada sifat fisik batuan yang ada[9]. Batuan dengan nilai tahanan jenis rendah menghantarkan arus listrik secara lebih baik dan sebaliknya batuan yang mempunyai tahanan jenis besar akan menghambat arus listrik. Batuan yang kompak dan masif serta terkonsolidasi dengan baik memiliki tahanan jenis yang rendah sehingga menghantarkan arus listrik secara lebih baik.

Konfigurasi yang digunakan adalah dipoledipole yang sensitif dalam mendeteksi perubahan vertikal maupun horisontal (lateral) dari suatu horison perlapisan batuan[9]. Konfigurasi dipole-dipole adalah konfigurasi yang elektroda arusnya diletakkan terpisah satu sama lain tergantung dari keperluan kedalaman intepretasi. Elektroda arus ditempatkan pada jarak minimum 5 kali jarak antara elektroda potensial yang terpasang.

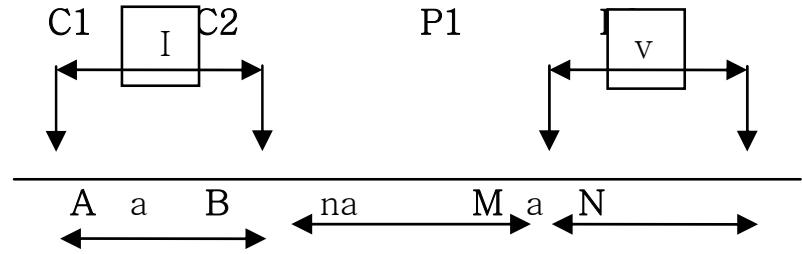

Keterangan

C1C2 : elektroda arus $\quad$ MN :Jarak elektroda potensial P1P2 : elektroda potensial AB : Jarak elektroda arus A : spasi elektroda I : kuat arus listrik (mA) $\mathrm{Na}$ :Jarak antar dipole $\mathrm{V}$ : beda potensial $(\mathrm{mV})$

Gambar 2. Konfigurasi dipole-dipole[9].

Pengukuran arus dan beda potensial untuk setiap jarak elektroda tertentu, dapat memberikan variasi harga hambatan jenis masing-masing lapisan di bawah titik ukur seperti ditunjukkan oleh Pers. (1) dan (2). Konfigurasi elektroda dipole-dipole, kedua elektroda arus dan elektroda potensial terpisah dengan jarak a. Sedangkan elektroda arus dan elektroda potensial bagian dalam terpisah sejauh na, dengan $\mathrm{n}$ adalah bilangan bulat. Variasi n digunakan untuk mendapatkan berbagai kedalaman. Skema konfigurasi dipole-dipole dapat dilihat pada Gambar 2, semakin besar $n$ maka kedalaman yang diperoleh juga semakin besar[9]. Indikasi patahan ditunjukkan oleh anomali nilai resitivitas/tahanan jenis yang relatif lebih rendah terhadap nilai tahanan jenis sekitarnya.

Dalam pengolahan untuk mendapatkan resistivitas/tahanan jenis menggunakan formula:

$$
\rho_{a}=k \frac{\Delta V}{I}
$$

dimana, $\rho_{a}$ adalah resistivitas semu $(\Omega) ; \mathrm{K}$ adalah faktor geometri; $\Delta \mathrm{V}$ adalah beda potensial (V); dan I adalah kuat arus (A).

Faktor geometri pada konfigurasi elektroda dipole-dipole[9] ditunjukkan pada persamaan 2 .

Tabel 1. Koordinat dan Azimuth Jalur Lintasan Pengukuran Geolistrik [6]

\begin{tabular}{lcccccc}
\hline \multirow{2}{*}{ Jalur } & \multicolumn{2}{c}{ Koordinat Patok Awal } & \multirow{2}{*}{ Arah } & \multirow{2}{*}{ Panjang } & \multicolumn{2}{c}{ Koordinat Patok Ahir } \\
\cline { 2 - 3 } \cline { 6 - 7 } & Lintang & Bujur & & Lintang & Bujur \\
\hline No 11 & 682604 & 9292629 & N81E & $500 \mathrm{~m}$ & 683072 & 9292707 \\
No 13 & 683247 & 9294833 & N80E & $500 \mathrm{~m}$ & 683731 & 9294917 \\
No 14 & 684258 & 9292024 & N72E & $500 \mathrm{~m}$ & 684733 & 9292184 \\
No 20 & 686611 & 9296596 & N36E & $500 \mathrm{~m}$ & 686901 & 9297003 \\
No 21 & 686385 & 9297127 & N48E & $500 \mathrm{~m}$ & 686738 & 9297453 \\
\hline
\end{tabular}




$$
\begin{aligned}
k & =2 \pi\left(\frac{1}{r 1}-\frac{1}{r 2}-\frac{1}{r 3}+\frac{1}{r 4}\right)^{-1} \\
& =2 \pi\left(\frac{1}{n a}-\frac{1}{a+n a}-\frac{1}{a+2 n a}-\frac{1}{a+3 n a}\right)^{-1} \\
& =\pi n a(1+n)(2+n)
\end{aligned}
$$

\section{METODE}

\subsection{Lokasi, Waktu dan Tahapan Penelitian}

Lokasi penelitian berada di Kawasan PUSPIPTEK Serpong, Desa Muncul wilayah Kecamatan Setu, Kota Tangerang Selatan, Banten. Secara geografis terletak pada posisi lintang 6 $6^{\circ} 21^{\prime} 26^{\prime \prime}$ LS dan bujur $106^{\circ} 39^{\prime} 37^{\prime \prime}$ BT. Secara umum daerah penelitian tersusun oleh sebaran endapan aluvial, tufa endapan gunungapi muda, berupa Formasi Serpong, Formasi Genteng dan Formasi Bojongmanik dengan perubahan variasi litologi secara vertikal maupun lateral[5]. Daerah penelitian merupakan dataran bergelombang rendah yang dibentuk dari produk hasil endapan volkanik G. Salak dan G. Pangrango [6].

Kegiatan penelitian dilakukan selama satu bulan (1-30 Mei 2015) untuk memperoleh data lapangan berupa endapan batuan, elemen struktur geologi dan resistivitas batuan, dilanjutkan pengolahan, analisis dan intepretasi.

Tahapan kegiatan meliputi pendataan geologi permukaan dan pendataan geolistrik. Pendataan geologi permukaan terdiri dari pengumpulan data beberapa sumber terkait daerah penelitian[11]. Kemudian intepretasi kelurusan terindikasi patahan menggunakan data DEM melalui identifikasi lembah sungai maupun lembah bukit yang berkontur sama, kelokan sungai yang diindikasikan adanya patahan[12]. Selanjutnya melakukan konfirmasi lapangan berdasarkan data kelurusan DEM, peta struktur geologi yang dipublikasikan dan peta rupa bumi untuk pendataan litologi dan elemen struktur geologi.

Pendataan geolistrik dilakukan untuk mendapatkan nilai resistivitas batuan menggunakan alat resistivitimeter pada lintasan yang telah ditentukan berdasarkan kelurusan data struktur geologi[9]. Pengukuran data dilakukan di area radius hingga $5 \mathrm{~km}$ dari tapak RDE memotong kalurusan yang diduga sebagai patahan hasil intepretasi sebelumnya. Tabel 1 menunjukkan hasil pengukuran dalam penelitian ini meliputi 5 jalur lintasan yang selanjutnya data diolah menggunakan program RES2DINV untuk mengetahui nilai tahanan jenisnya.

\subsection{Langkah Kerja}

Peralatan geolistrik terdiri dari resistivitimeter (termasuk sumber arus), kabel arus dan potensial serta elektroda. Sumber listrik dari resistivitimeter menggunakan elektroda yang ditancapkan ke dalam lapisan yang keras, agar terjadi ground coupling yang bagus sehingga akan didapatkan data berkualitas bagus. Data logger dalam resistivitimeter merekam sinyal yang dan kemudian disimpan dalam bentuk file yang dapat diunduh menggunakan perangkat lunak RES2DINV. Lembar data dan kurva lapangan dicantumkan kondisi geologi/hidrogeologi serta topografi sekitar lokasi pengukuran. Lokasi pengukuran berupa lintasan geolistrik yang diplot pada peta topografi/peta rupa bumi skala 1:25.000. Pada pengukuran sounding resistivity 1D hasil pengukuran lapangan dilakukan proses matching curve menggunakan kurva standar[13]. Sedangkan pada pengukuran geolistrik 2D, hasil langsung diolah menggunakan perangkat lunak RES2DINV.

\section{HASIL DAN PEMBAHASAN}

Hasil konfirmasi lapangan untuk pendataan geologi menunjukkan bahwa batuan penyusun daerah Serpong dan sekitarnya terdiri dari tiga Formasi yang ditutup oleh endapan Alluvium paling muda. Berturut-turut formasi mulai paling atas/muda sampai paling bawah/tua adalah Formasi Serpong, Formasi Genteng dan Formasi Bonjongmanik[14]. Tapak RDE secara litologi tersusun dari batuan sedimen yang didominasi oleh endapan batupasir gampingan, material konglomerat serta batupasir tufaan bagian dari Formasi Genteng. Formasi Bojongmanik muncul di beberapa lokasi yang merupakan formasi paling bawah sebagian telah mengalami tektonik yang dibuktikan dengan munculnya kekar-kekar di beberapa tempat. Berdasarkan 
intepretasi DEM memperlihatkan kelurusan yang diduga sebagai patahan berarah Baratlaut-Tenggara[15]. Berdasarkan dari kelurusan terindikasi patahan tersebut dilakukan pengukuran geolistrik yang dikelompokkan menjadi dua jalur pengukuran, yaitu bagian barat dan timur dari Sungai Cisadane.

Hasil pengolahan data geolistrik disajikan dalam bentuk penampang lintang resistivitas. Penampang lintang tersebut berisi sebaran nilai resistivitas yang diwakili oleh warna-warna yang berbeda. Warna biru mempunyai arti nilai resistivitas rendah sedangkan warna kuning muda hingga kuning tua memiliki arti nilai restivitas semakin besar[9,14]. Analisa data dilakukan secara kualitatif terhadap peta penampang lintang resistivitas 2D, sehingga diperoleh perbedaan resitivitas yang menunjukkan dugaan patahan. Pengukuran geolistrik dibatasi pada jalur yang terbukti ada kelurusan berarah BaratlautTenggara dari data DEM dan data geologi. Jalur tersebut adalah Jalur 11, Jalur 13, Jalur 14, Jalur 20, Jalur 21 (Gambar $3-7$ ).

Berdasarkan penampang nilai tahanan jenis dari pengukuran pada jalur-jalur tersebut, tidak terlihat perubahan nilai tahanan jenis secara tiba-tiba. Nilai tahanan jenis yang berubah secara tiba-tiba mengiindikasikan adanya patahan/struktur geologi. Perolehan hasil nilai tahanan jenis dapat dikelompokkan menjadi 3, yakni nilai tahanan jenis dengan nilai kurang dari 7.53 Ohm.m, 7.53 - 56.7 Ohm.m dan diatas 56.7 Ohm.m, yang diinterpretasikan mewakili jenis litologi atau tingkat kejenuhan kandungan air yang berbeda. Pelapisan batupasir, lempung tufaan umumnya mengandung banyak air, memiliki nilai tahanan jenis yang relatif kecil atau lebih kecil dari 7,53 Ohm.m, dan pelapisan batu lempung, konglomerat yang mengandung air cukup memiliki nilai tahanan jenis antara 7,53 - 56,7 Ohm.m. Sedangkan pelapisan batuan masiv, andesit, basalt yang mengandung sedikit air memiliki nilai tahanan jenis lebih besar dari 56,7 Ohm.m [16, 17]. Secara keseluruhan hasil analisis Jalur J-11, J-13, J14, J15 dan J-20 diperlihatkan secara berturutan pada Gambar $3-7$. Nilai tahanan jenis kecil, kurang dari 7.53 Ohm.m biasanya muncul di daerah topografi rendah, lembahlembah sungai, bekas daerah penambangan bahan galian yang telah berubah menjadi genangan-genangan air/rawa-rawa [19]. Kenampakan hasil tersebut terlihat pada Gambar 3, 4 dan 7. Sedangkan pada Gambar 5 dan 6 nilai tahanan jenis relatif kecil muncul di bagian tengah membentuk kenampakan suatu horison menerus yang diinterpretasikan sebagai lapisan pembawa air (akuifer).

Perubahan litologi di bawah permukaan tercermin oleh perubahan nilai tahanan jenis secara gradual. Nilai tahanan jenis batuan yang rendah mengindikasikan lapisan berisi kandungan air, sedangkan nilai tahanan jenis tinggi mengindikasikan batuan yang masif dan kompak.

Jalur lintasan pengukuran geolistrik yang berada di sungai Cisadane bagian timur, lokasi ini diintepretasikan memiliki litologi yang didominasi oleh batupasir gampingan (Formasi Bojongmanik), konglomerat (Formasi Serpong) dan tufa endapan gunung api muda (Gn. Salak) [18].

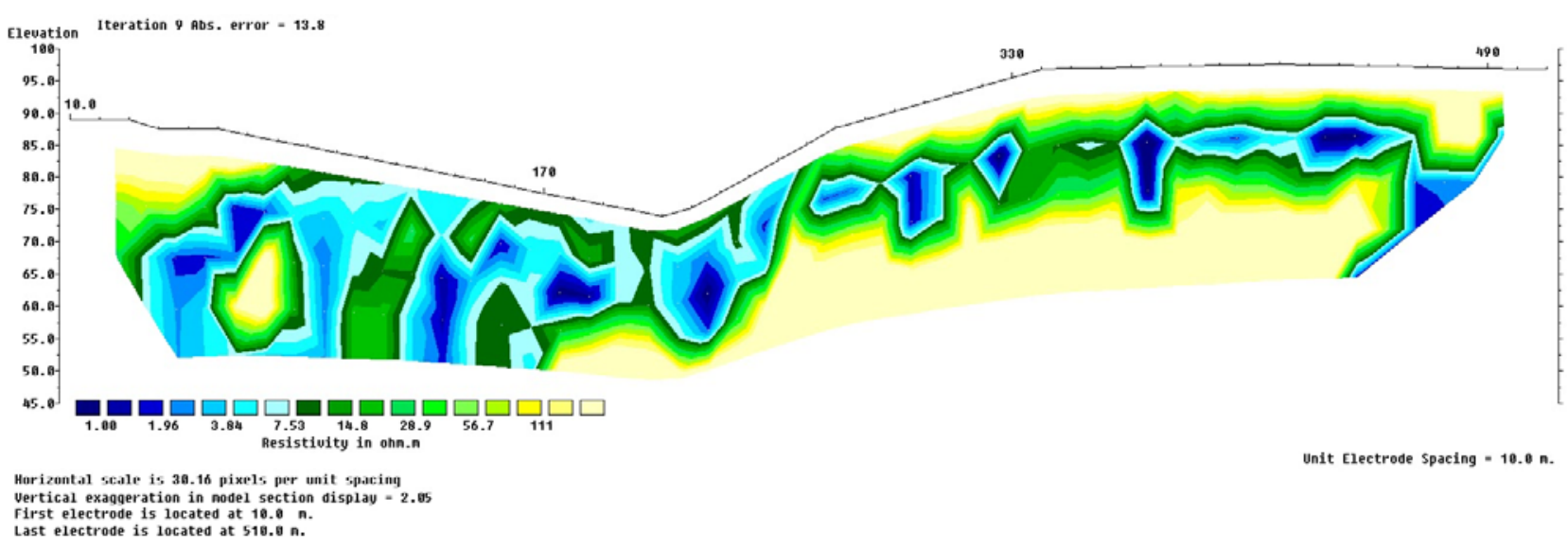

Gambar 3 Penampang Tahanan Jenis Jalur 11. 


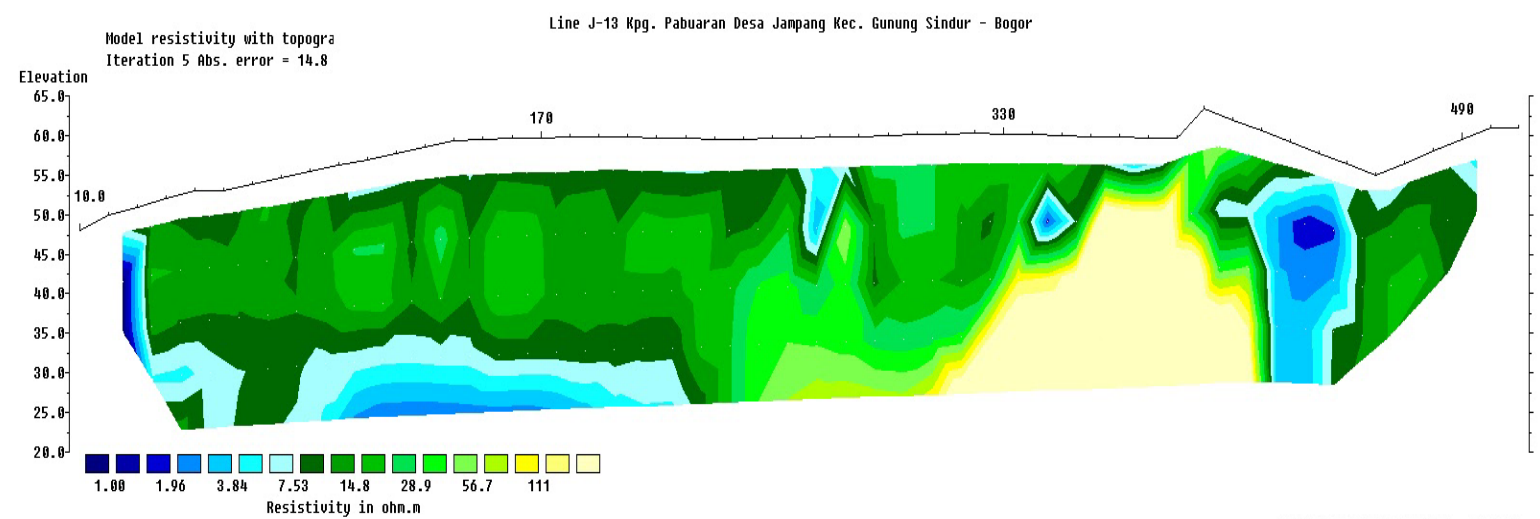

Horizontal scale is 39.16 pixels per unit spacing

Uertical exaggeration in model section display $=2.85$

Unit Electrode Spacing $=19.8 \mathrm{~m}$ First electrode is located at $18.8 \mathrm{~m}$.

Gambar 4. Penampang Tahanan Jenis Jalur 13.

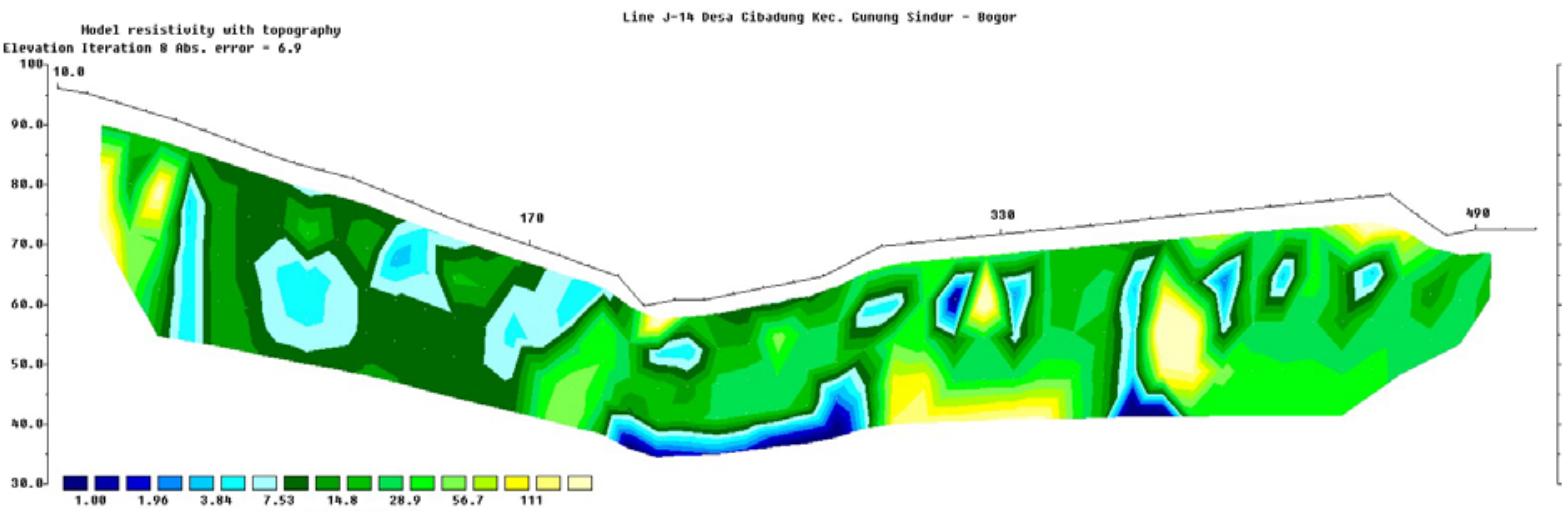

$\square_{1.00} \square_{1.96} \square_{3.84} \square_{7.53} \square_{14.8} \square_{28.9} \square_{56.7} \square_{11} \square \square$

Horizontal scale is 30.38 pixels per unit spacing
Uertical exageration in podel section display -1.90

First electrode is located at $10.8 \mathrm{n}$.

Gambar 5. Penampang Tahanan Jenis Jalur 14.



Horizontal scale is 30.38 pixels per unit spacing

Vertical exaggeration in model section display $=1.99$

First electrode is located at $18.8 \mathrm{~m}$.

Unit Electrode Spacing $=19.8 \mathrm{~m}$

Gambar 6. Penampang Tahanan Jenis Jalur 20. 


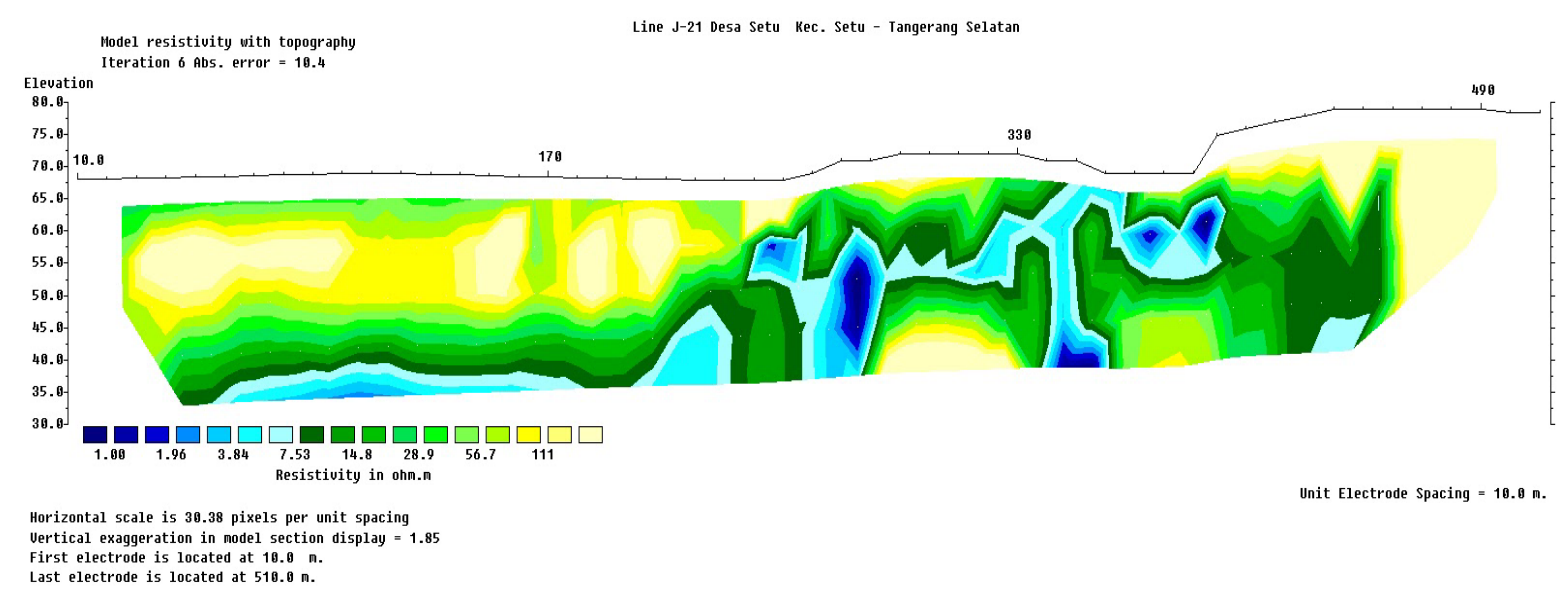

Gambar 7. Penampang Tahanan Jenis Jalur 21.

Jalur J-11 pada Gambar 3 berada di desa Jampang, Kec. Gunung Sindur, lintasan geolistrik memotong sebuah kelurusan yang sejajar Sungai Cisadane, dan berada pada sebaran Formasi Bojongmanik dan Formasi Serpong. Dari penampang tahanan jenis yang dihasilkan menunjukkan adanya indikasi beberapa zona lemah, dicirikan nilai tahanan jenis rendah, yang memotong suatu horison yang memiliki nilai tahanan jenis lebih tinggi seperti terlihat pada Jalur J-13. Pada penampang J-11, zona lemah terlihat pada bentang ke $150 \mathrm{~m}$ dan $230 \mathrm{~m}$.

Jalur J-11, J-13, J-14, berada di kelurusan lembah Sungai Cisadane (Gambar 1) dan termasuk dalam Formasi Bojongmanik yang berumur tua dan diatasnya berupa batuan tufa endapan gunung api muda berumur kuarter[6]. Dari ketiga penampang tersebut hanya satu (J-13) yang memperlihatkan adanya perubahan nilai tahanan jenis secara signifikan atau horison terpotong oleh tahanan jenis tinggi (>55.0 Ohm.m). Sayatan ini mengindikasikan struktur geologi. Namun jika dilihat dari data geologi permukaan tidak menunjukkan patahan. Variasi nilai tahanan jenis bisa terjadi akibat adanya perubahan litologi, fasies, formasi ataupun kandungan airnya.

Kemenerusan horizon dengan nilai tahanan jenis relatif rendah $(7.53$ - 56.7 Ohm.m) di bagian tengah penampang mengindikasikan lapisan pembawa air atau akuifer, dan nilai $>56.7$ Ohm.m di bagian bawah penampang diinterpretasikan sebagai suatu massa batuan yang sifatnya lebih masif, kemungkinan batugamping bagian dari Formasi Bojongmanik seperti terlihat pada Gambar 4.
Penampang tahanan jenis dari J-20 dan J-21, berada pada sebaran tufa endapan gunung api muda (Gn. Salak) Formasi gunungapi muda. Variasi nilai tahanan jenis terjadi akibat perubahan litologi dari tufa di bagian atas menjadi batuan yang bersifat lebih porous dan permeabel dibagian bawahnya, bagian dari F. Bojongmanik $(<56.7$ Ohm.m) dan tidak terlihat adanya perubahan nilai tahanan jenis secara signifikan atau horison yang terpotong yang mengindikasikan struktur geologi. Penampang tahanan jenis J-21 pada Gambar 7 terlihat bahwa ketebalan Formasi Genteng yang tersusun atas batupasir tufaan secara umum memiliki dengan ketebalan mencapai $\pm 40 \mathrm{~m}$, sedangkan didekat permukaan memiliki nilai tahanan jenis yang relatif tinggi $(>56.70 \mathrm{hm} . \mathrm{m})$ dan tidak menunjukkan patahan.

\section{KESIMPULAN}

Hasil identifikasi struktur geologi permukaan menunjukkan tidak adanya pensesaran permukaan/patahan kapabel pada radius $5 \mathrm{~km}$ dari tapak RDE. Arah kelurusan Baratlaut-Tenggara merupakan intepretasi DEM yang dibuktikan dengan pengukuran geolistrik konfigurasi dipole-dipole hasilnya tidak memperlihatkan bukti adanya patahan.

Kelurusan sebagai dugaan patahan tersebut kemungkinan akibat erosi sungai maupun resistensi batuan. Beberapa penampang mengindikasikan zona lemah yang menunjukkan nilai tahanan jenis rendah merupakan cekungan zona akuifer. Variasi nilai tahanan jenis lebih banyak dipengaruhi 
karena adanya perbedaan litologi baik lateral maupun vertikal dan perbedaan tingkat kejenuhan air. Susunan pelapisan batuan daerah Serpong didominasi oleh batuan sedimen berupa pasir dan lempung.

\section{UCAPAN TERIMA KASIH}

Penulis mengucapkan terima kasih kepada Bapak Ir. Yarianto SBS, MSi Kepala Pusat PKSEN yang telah memberi arahan dan bimbingan pada penelitian ini. Kepada Bapak Ir. Sriyana MT, Kepala Bidang KDT yang telah mengkoreksi untuk kebaikan penelitian ini hingga selesai dan tidak lupa terima kasih kepada kawan-kawan di Bidang KDT yang telah membantu hingga selesainya penelitian ini.

\section{DAFTAR ACUAN}

[1]. Natawidjaya, D. H., "Evaluasi Bahaya Patahan Aktif, Tsunami dan Goncangan Gempa," Laboratorium Riset Bencana Alam Geoteknologi, LIPI, Jakarta, 2007.

[2]. Evaluasi Aspek Kegempaan untuk Keselamatan Reaktor Nuklir, Peraturan Kepala Bapeten No. 08/Ka-BAPETEN/VI-2013, 2013.

[3]. Evaluasi Keselamatan Tapak Nuklir, Peraturan Kepala Bapeten No. 05/Ka-BAPETEN/VI-2007, 2007.

[4]. Site Evaluation for Nuclear Installation, Safety Requirements No. NS-R-3, IAEA Safety Standards Series, 2003.

[5]. Turkandi, T, dkk, "Peta geologi lembar Jakarta dan Kepulauan Seribu, skala 1 : 100.000”, Puslitbang Geologi, Bandung, 1992.

[6]. _ _Laporan Evaluasi Tapak Reaktor Daya Eksperimental, Aspek Kegempaan,” Pusat Kajian Sistem Energi Nuklir-BATAN, Jakarta, 2015.

[7]. Howell, Jr., B. F., Introduction to Geophysics, New York, USA, McGraw-Hill, 1950.

[8]. Hadi Suntoko, "Pendeteksian Keberadaan Struktur Sesar pada Batuan Vulkanik dengan Meotode
Magnetik”. Jurnal Eksplorium, Vol 33 No.2, November 2012, Hal. 111-120.

[9]. Satuti Andriyani dkk., "Metode Geolistrik Imaging Konfigurasi Dipole dipole Digunakan Untuk Penelusuran Sistem Sungai Bawah Tanah Pada Kawasan Karts Di Pacitan, Jawa Timur”. Jurnal EKOSAINS Vol. II, No. 1, Maret 2010, Hal. 46-54.

[10]. Hadi Suntoko, Ari Nugroho, "Analisis Gradien Horizontal (Graviti) Untuk Konformasi Awal Sesar Permukaan di Banten". Jurnal Pengembangan energi Nuklir Vol.13, No.2, Desember 2011, Hal. 72-80.

[11]. Hadi Suntoko, June Mellawati, "Studi Pra-survei Pulau Panjang, Banten sebagai Daerah Interes PLTN", Prosiding Seminar Nasional Pengembangan Energi Nuklir ke-III, Jakarta, 18 Juni 2010.

[12]. Hadi Suntoko, Ari Nugroho, "Tinjauan Aspek Pensesaran Permukaan Regional Terhadap Keselamatan Tapak di Banten", Prosiding Seminar Nasional Pengembangan Energi Nuklir ke-III, Jakarta, 18 Juni 2010.

[13]. Rohim, N T., Heru S, Nunjil H., “Aplikasi Metode Geolistrik Sounding Dengan Konfigurasi Pole-Pole Untuk Mengukur Resistivitas Bawah Permukaan Tanah Dan Mengetahui Struktur Tanah,” PKM-GT, Universitas Negeri Malang, Malang, 2010.

[14]. Minarto, E., dan T. Astoro. (2018, 02 Desember). Identifikasi Struktur sesar Bawah Permukaan, dengan menggunakan Konfigurasi HalfSchlumberger (Head-on) pada eksplorasi panasbumi Daerah Mataloko [Online]. Available: http://personal.its.ac.id/files/pub/1695-minartophysics-PENELITIAN_MATALOKO.pdf

[15]. Hadi Suntoko, Supartoyo Supartoyo, "Konfirmasi Patahan Permukaan Awal Berdasarkan Data Geologi Dan Data Gempa Daerah Kawasan PUSPIPTEK Serpong”. Jurnal Pengembangan Energi Nuklir Vol. 18, No. 1, Juni 2016, Hal. 1-10.

[16]. Telford, W.M., Goldrat, L.P., and Sheriff, R.P., Applied Geophysics, 1st ed. Cambridge, Cambridge University Pres, 1976.

[17]. Telford, W.M., Goldrat, L.P., and Sheriff, R.P., Applied Geophysics, 2nd ed, Cambridge, Cambridge University Pres, 1990.

[10]. Marjiyono, dkk., "Kelas Soil Daerah Sekitar Rencana Tapak Reaktor Daya Eksperimental (RDE) Serpong Dari Data Mikrotremor, 2015”. Jurnal Pengembangan Energi Nuklir Vol 17, No 1, Juni 2015, Hal. 57-66 